\title{
Maitotilojen tilanpidon ja liikkeenjohdon kehittämistarpeet Pohjois- Savossa
}

\author{
Tero Kanala ${ }^{1)}$, Risto Kauppinen ${ }^{1)}$, Seppo Mönkkönen ${ }^{1)}$, Mika Repo ${ }^{2)}$, Anne-Mari Heikkinen ${ }^{2)}$ \\ 1) Savonia ammattikorkeakoulu, Iisalmi etunimi.sukunimi@savonia-amk.fi \\ ${ }^{2)}$ Maito-Savo, Aluekehityssäätiö/Ylä-Savon instituutti etunimi.sukunimi@aluekehityssaatio.fi
}

\section{Tiivistelmä}

Suurentuva tilakoko ja muuttuva toimintaympäristö luovat uusia haasteita maatilan toimintojen järjestämiselle ja työn käytölle. Oma työpanos ei riitä enää kaikkiin töihin, joten toimintaa on priorisoitava niihin töihin, joista on paras tietotaito. Liikkeenjohto ja siihen liittyvien ratkaisujen tekeminen kuuluvat aina yrittäjälle.

Maitotilojen tilanpitoon ja liikkeenjohtoon liittyviä kehittämistarpeita tutkittiin Pohjois-Savossa lypsykarjatiloille suunnatulla kyselyllä, jossa selvitettiin maitotilan pitkän tähtäimen päätöksiin vaikuttavia tekijöitä, liikkeenjohdollisia taitoja, työn käyttöä, yrittäjän henkistä kasvamista, toimimista verkostoissa, tilan tuotantoteknologisia ratkaisuja ja ulkopuolisten palvelujen käyttöä. Kysely lähettiin 500 maitotilalle, joista kyselyyn vastasi 193 tilaa (vastausprosentti 39,0). Lisäksi haastateltiin 20 lypsykarjatilaa. Tutkimus toteutettiin vuoden 2007 aikana.

Tämän tutkimuksen mukaan maidontuotantoa jatkavilla tiloilla on runsaasti investointisuunnitelmia: Koneisiin aikoo investoida $83 \%$ tiloista, rakennuksiin $69 \%$, maatalousmaahan $44 \%$ ja eläimiin $44 \%$. Maitotiloista $80 \%$ aikoo jatkaa vähintään vuoteen 2013. Samaan aikaan lypsylehmien määrä/tila kasvaa nykyisestä 22 lehmästä noin 30 lehmään ja lehmien keskituotos kohoaa noin 1,5\% vuodessa. Maidon kokonaistuotanto näyttäisi tuottajien suunnitelmien toteutuessa kasvavan PohjoisSavossa $12 \%$ nykyisestä vuoteen 2013 mennessä. Neljä tilaa viidestä ilmoittaa tarvitsevansa lisätyövoimaa. Työvoimatarve täytettäisiin mieluiten urakointipalveluilla, mutta myös palkkaamalla tilapäisiä työntekijöitä. Tuottajat haluavat hoitaa tarkkuutta vaativat työt omalla työpanoksella, jolloin laatuun kyetään panostamaan enemmän. Vaikka ns. tilan ulkoisten tekijöiden merkitys päätöksenteossa on tärkeä, viljelijän lähipiirissä olevat tekijät nousevat tärkeimmiksi. Näitä ovat mm. oma työssä jaksaminen, perhe, oma ammattitaito sekä vapaa ajan riittävyys.

Haastatteluiden mukaan talouden aktiivinen seuranta on kuitenkin varsin vähäistä ja perustuu usein kokemukseen. Yrittäjät olivat hyvin perillä talouden hetkellisistä vaikutuksista, mutta pitkäntähtäimen suunnitelmia tai vaikutuksia ei osattu arvioida. Talouden seurannan ja toiminnan analysoinnin puutetta perusteltiin tilan suurella kokonaistyömäärällä. Perinteisen isännän ja emännän välisen työnjaon ja päivittäisten työrutiinien muuttuminen vaikeuttaa töiden tekemisen johdonmukaisuutta.

Tilojen tavoitteellinen kehittäminen kaipaa selkeämpää johdonmukaisuutta. Tavoitteiden asettaminen tulisi olla täsmällisempää ja selkeämmin priorisoitua ns. avaintavoite-asettelua. Niihin tulisi liittää selkeä toimintasuunnitelma ja saavutukset tulisi analysoida kriittisesti. Tilaa voidaan kehittää, joko investoimalla tai toimintaan panostamalla. Ajankäyttö ja rutiinien johdonmukaisuus edellyttävät tiloilta työnjohto-osaamista. Yrittäjän on tärkeää huolehtia lähitekijöiden (oma työssä jaksaminen, perhe, oma ammattitaito, vapaa ajan riittävyys) toimivuudesta.

Asiasanat: maatalousyritykset, liikkeenjohto, johtaminen, kehittäminen 


\section{Johdanto}

Maatalouden toimintaympäristön muutos tuo lisää haasteita maidontuotantoon. Tuottajana viljelijä ei kykene juurikaan vaikuttamaan maidon tuottajahintaan, sen sijaan maatalousyrittäjänä tuottajalla on mahdollisuus vaikuttaa tilansa toimintaan ja sitä kautta tulotasoonsa. Tilakoko on kasvamassa, mikä asettaa haasteita tuotantorakenteelle ja sekä yrittäjälle, kasvaa yrityksensä mukana.

Pohjois-Savo on merkittävä maidontuotanto alue Suomessa. Suomalaisesta maidosta vuonna 2005 noin 13 \% tuotettiin Pohjois-Savon alueella. (Suomen Gallup Elintarviketieto Oy. 2006) Maidontuotannon uskotaan tulevaisuudessa keskittyvän enemmän C1-C2 alueille. (Lehtonen 2007). Maidontuotannon kilpailukyky kansainvälisessä toimintaympäristössä suosii tilakoon kasvua. Tämä edellyttää, että tilat ovat valmiita muutokseen ja omaksuvat uusia toimintatapoja ja käytänteitä. Tilakoon kasvu vaatii yrittäjältä uusia valmiuksia.

Tämän tutkimuksen tarkoituksena on selvittää millaisia ovat maitotilojen kehittämisnäkymät yrittäjien näkökulmasta ja millaisiin kehittämistarpeisiin tulevaisuudessa on varauduttava. Tärkeää on myös löytää kysymyksiä, mitkä askarruttavat yrittäjiä. Selvityksen tuloksia on tarkoitus käyttää suuntaamaan hankkeistettuja kehittämisteemoja ja hakea painopisteitä koulutustoimintaan ja neuvontaan, vastaamaan paremmin yrittäjien tarpeita.

Tavoitteena on ollut myös selvittää millaiset valmiudet pohjoissavolaisilla maidontuottajilla on vastata tulevaisuuden haasteisiin ja kehittää toimintaansa ajan vaatimukset huomioiden. Laajentavilla tiloilla ei oma työpanos välttämättä enää riitä tilan toiminnan ylläpitoon, ainakaan perinteisillä menetelmillä. Tämä vaatii toiminnan tehostamista ja priorisointia sekä toiminnan uudelleen organisointia. Talouden merkitys kasvaa vieraan pääoman ja liikevaihdon kasvun myötä. Laajeneva tila antaa toisen tyyppiset mahdollisuudet hyödyntää erilaisia logistisia ratkaisuja. Tilan toimintakulttuurin muutos edellyttää laajempaa prosessien tuntemusta sekä kykyä johtaa prosesseja.

\section{Aineisto ja menetelmät}

Esiselvitys toteutettiin kolmessa vaiheessa tammikuun ja syyskuun 2007 aikana. Tilojen taustoja ja tavoitteita selvitettiin Pohjois-Savon maitotilabarometri kyselyn yhteydessä vuoden 2007 keväällä. Kysely lähetettiin 500 satunnaisesti valitulle maitotilalle. Vastaus saatiin 193 yrittäjältä (vastausprosentti $39 \%$ ). Saatuja tuloksia tarkennettiin 20 maitotilalle suunnatulla syventävällä haastattelulla. Tuloksia peilattiin syksyllä 2007 tanskalaisten maitotilojen toimintatapoihin ja - malleihin.

Kyselyssä pyrittiin selvittämään pohjoissavolaisten tilojen toiminnan kokoa ja rakennetta sekä yrittäjien omia tavoitteita vuoteen 2013 asti. Lisäksi selvitettiin tilojen päätöksen tekoon vaikuttavia tekijöitä sekä tyytyväisyyttä tilan eri osa-alueisiin. Pohjois-Savon maitotilabarometrikysely liittyy Suomen maitotilabarometri tutkimukseen. Kyselyn tulokset analysoitiin Suomen Gallup Elintarviketieto Oy:ssä.

Tutkimuksessa haastateltiin kevään ja kesän 2007 aikana 20 maidontuottajaa. Näistä puolet oli merkittävästi laajentanut tuotantoaan 2000 luvun aikana. Haastattelututkimuksen tarkoituksena oli selvittää mm. laajentaneiden tilojen muutosprosessia ja kehittämistarpeita muutosprosessiin liittyen. Kyselyn ja sitä täydentävän syventävän haastattelun kautta saatiin otos, jossa oli mukana tiloja kattavasti koko maakunnasta ja lisäksi sellaisia, jotka olivat voimakkaasti kehittäneet toimintaansa joko investoimalla tai tehostamalla muutoin omaa toimintaansa.

Haastatteluissa keskityttiin yleisesti tilan ydinprosesseihin, kuten talouteen, rehun- ja maidontuotantoon sekä niiden kehittämiseen ja mahdollisiin ongelmakohtiin. Haastatteluissa selvitettiin myös tilan tulevaisuuden suunnitelmia. Lisäksi laajentaneilla tiloilla selvitettiin muutosta kokonaisuutena ja muutoksen tuomia haasteita.

Syyskuussa 2007 toteutettiin tutustumismatka Tanskaan. Matkan tarkoituksena oli perehtyä Tanskassa tapahtuneeseen maitotilojen rakennemuutokseen ja siihen, miten tanskalaiset tilat ovat sopeuttaneet toimintaansa ja kokeneet muutosprosessit. Lisäksi peilattiin Suomessa kyselyn ja haastattelun kautta esiin nousseita kysymyksiä ja tarpeita tanskalaisten tilojen toimintaan ja etsittiin sovellettavia käytänteitä.

\section{Tulokset ja tulosten tarkastelu}

Pohjois-Savossa on erittäin vahva usko maidontuotannon tulevaisuuteen. Neljä viidestä maidontuottajasta aikoo jatkaa tuotantoa ainakin vuoteen 2013 asti. (KUVIO 1) Tämä tarkoittaa käytännössä noin 1400 maitotilaa. Maitotilojen koko on myös kasvamassa. Erityisesti lypsylehmien määrä on nouse- 
massa 1-1,5 eläimellä vuodessa. (KUVIO 2) Keskituotoksen kasvun tavoitteeksi on asettanut yli puolet tiloista. (KUVIO 3) Tätä tukee myös se, että yrittäjät katsovat eläinaineksen olevan tilan toiminnan vahvuuksia. Mikäli yrittäjien suunnitelmat toteutuvat, maidontuotanto on kasvamassa seuraavana kuuden vuoden aikana yli kymmenyksen. (KUVIO 4) Tämä tarkoittaa Suomen Gallup Elintarviketieto Oy:n (2006) mukaan, että maidontuotanto kasvaa noin 6-8 prosenttiyksikköä nopeampaa kuin muualla Suomessa. Tämä tukisi myös Lehtosen näkemystä, että maidontuotanto on keskittymässä C1-C2 tukialueille.
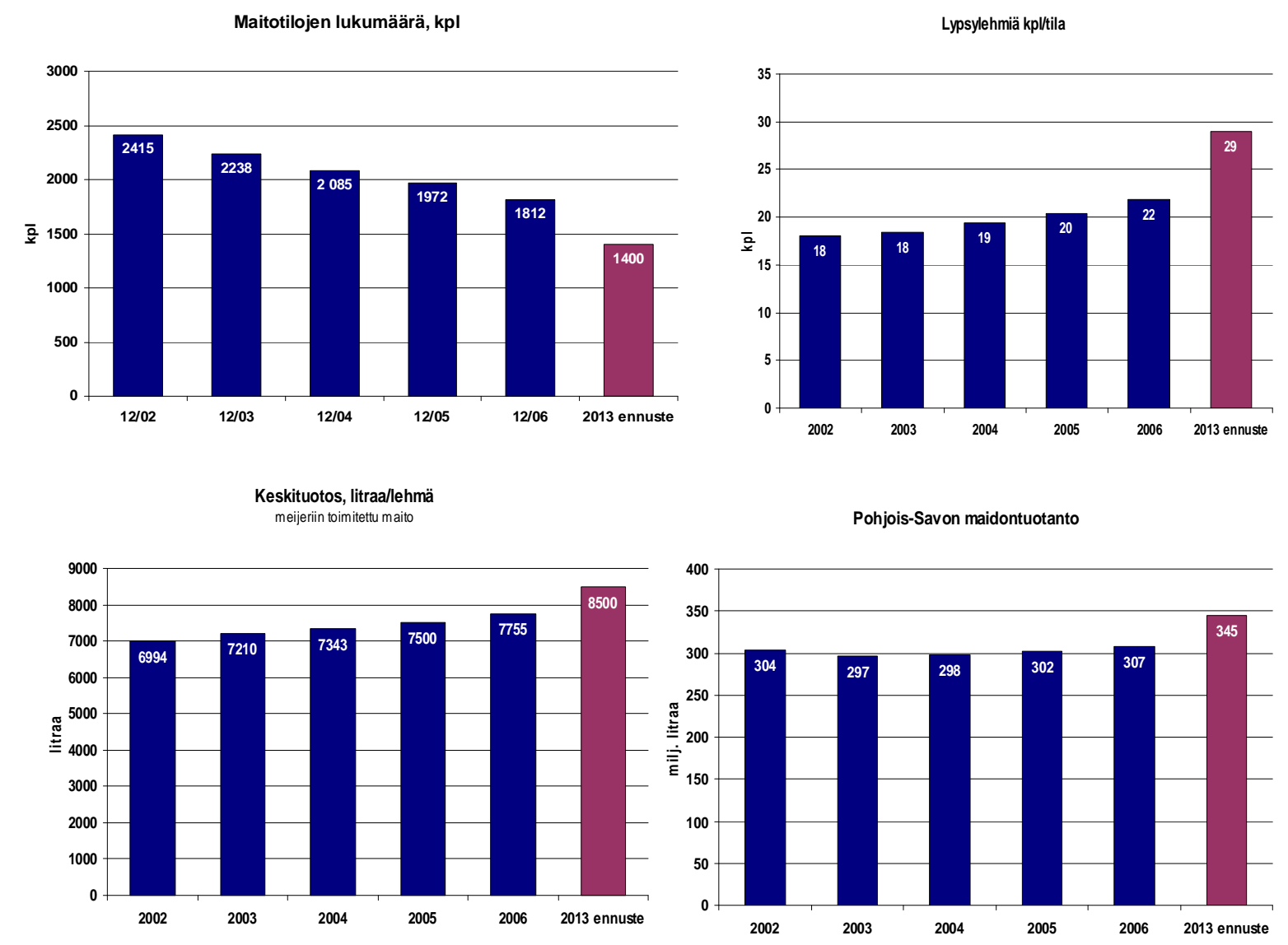

KUVIOT 1, 2, 3 ja 4. Maidontuotannon kehitys Pohjois-Savossa 2002-2006 ja tuottajien näkemykset vuodesta 2013.

Eläinmäärän kasvusta huolimatta peltoon ei olla juurikaan investoimassa. Alle viidenneksellä tiloista on tarkoitus lisätä peltoalaa, joskin lähes puolet tiloista on varaamassa rahaa peltoinvestointeihin. Pellon saanti koetaan tilan toiminnan esteeksi, joskin peltojen kunto taas on ollut usein tilan vahvuutena. Tämän kyselyn mukaan enää kymmenes yrittäjistä olisi valmis hoitamaan yli 100 ha tilaa kun 2004 lähes puolet yrittäjistä oli tähän valmiita. Eläinmäärän suhteen valmius suurten karjojen hoitoon on kuitenkin nousemassa tasaisesti. Yrittäjät haluavat keskittyä tuotantorakennuksessa tapahtuviin toimintoihin. (KUVIOT 5 ja 6)
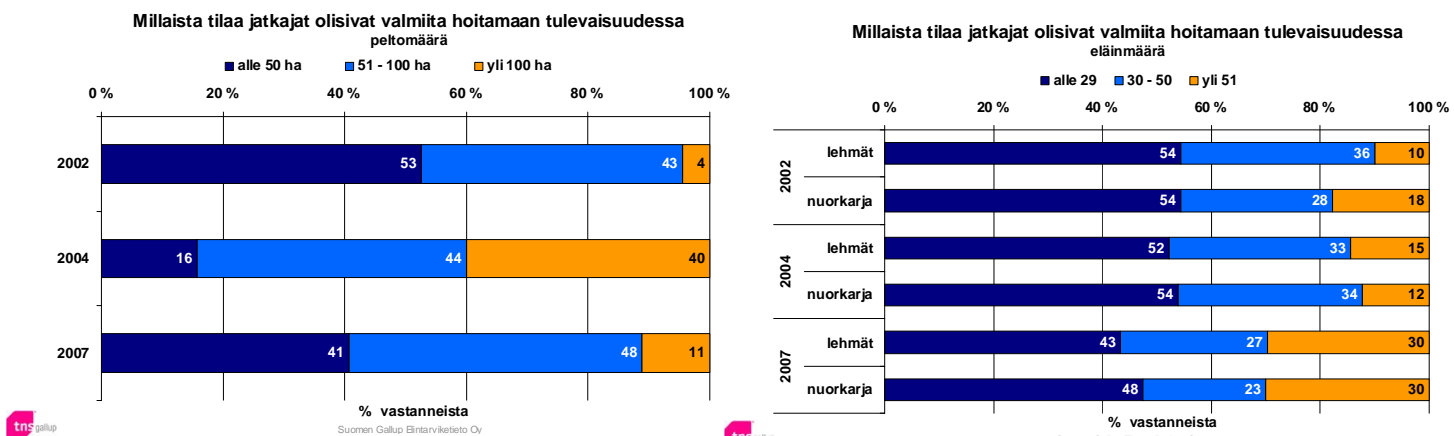

KUVIOT 5 ja 6. Yrittäjien valmiudet erikokoisten tilojen hoitamiseen Pohjois-Savossa. 
Maatilojen päätöksentekoon vaikuttaa vahvasti oma jaksaminen ja ajan käyttö. (KUVIO 7) Tärkeimmiksi päätöksentekoa ohjaavaksi tekijäksi nimettiin oma työssä jaksaminen, perhe ja viidenneksi yltänyt oma vapaa-aika. Huoli omasta hyvinvoinnista tuli esiin myös haastatteluissa joissa seitsemän erityisesti mainitsi oman terveytensä tilan toiminnan riskiksi. Riskiin pyrittiin varautumaan hyvillä työtavoilla ja huolellisella työnteolla. Vain yksi tila mainitsi varautumiskeinoksi työohjeiden laatimisen ja päivittämisen. Päätöksenteossa näkyy myös nopeasti muuttuva toimintaympäristö. Pienimmän merkityksen saivat muut viljelijät sekä maatalouteen liittyvä kauppa ja eri organisaatiot. Uusiin tuotantorakennuksiin ollaan myös investoimassa tulevaisuudessa. Kymmenen prosenttia kyselyyn vastanneissa jatkavista tiloista suunnittelee yli 250000 euron investointia rakentamiseen. (KUVIO 8)

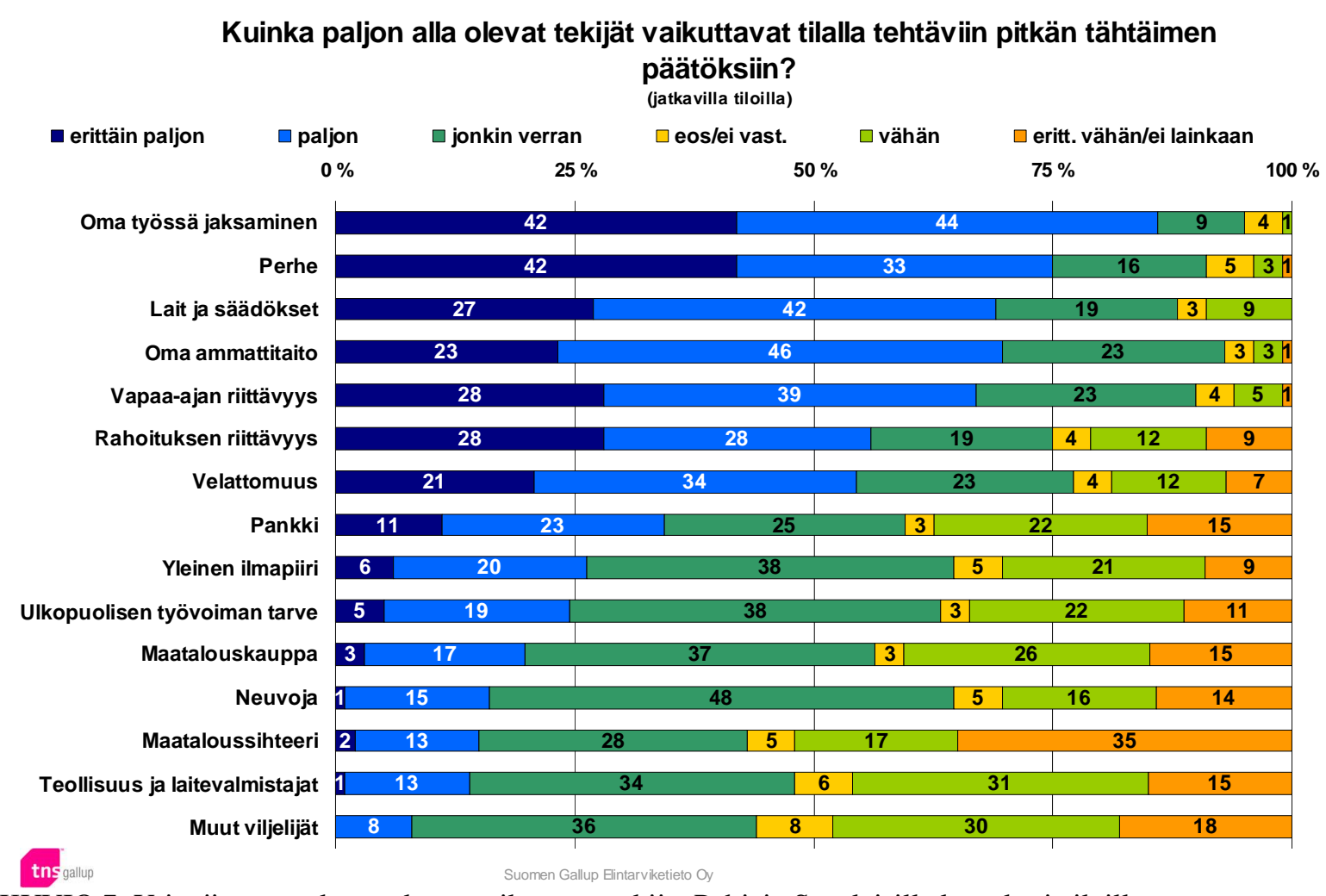

KUVIO 7. Yrittäjien päätöksen tekoon vaikuttavat tekijät Pohjois-Savolaisilla lypsykarjatiloilla.

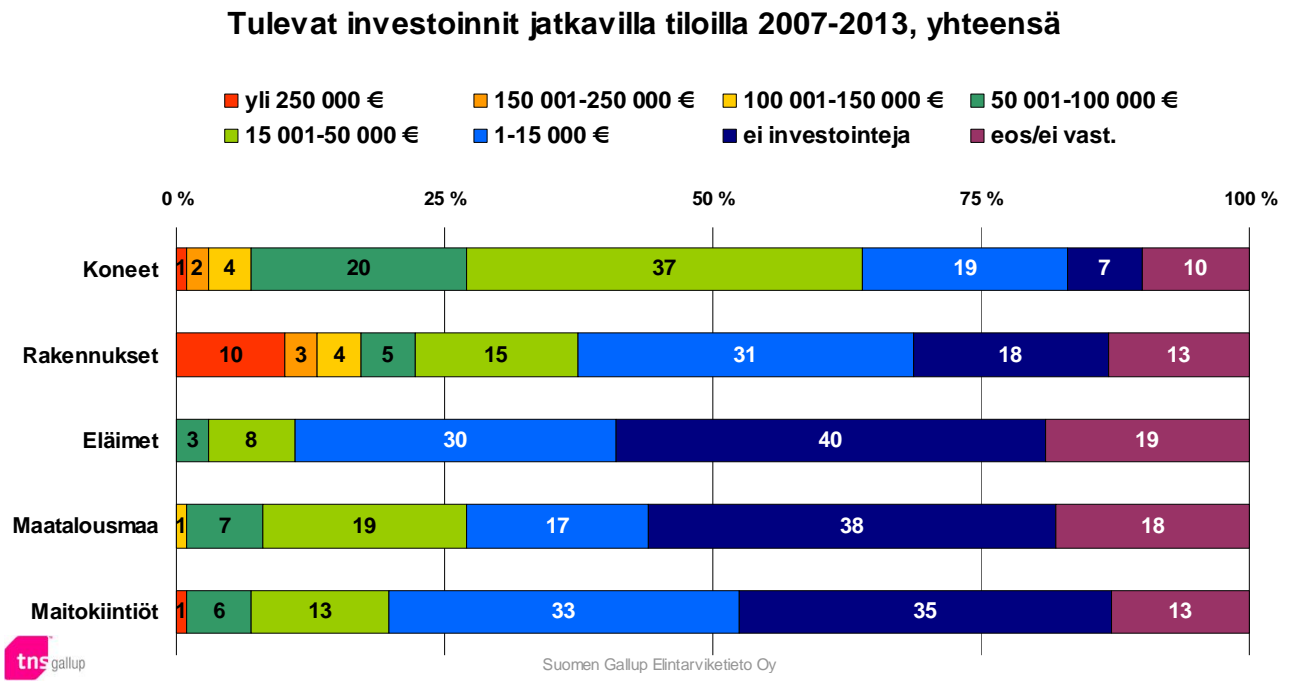

KUVIO 8. Yrittäjien suunnittelemat investoinnit Pohjois-Savossa 2007-2013. 
Yli $75 \%$ vastaajista oli tyytyväisiä asetettujen tavoitteiden (tilakohtaiset, perhe, ympäristö) saavuttamiseen. (KUVIO 9) Perhesuhteisiin oltiin tyytyväisimpiä, mutta työvoimaan tyytyväisyys oli vähäisintä. Tähän vaikuttaa maatilojen työmäärä ja jatkavista tiloista neljä viidestä ilmoittaa, että tilalla olisi tarve tilapäiselle työvoimalle. Tilan toimintoja haluttaisiin ulkoistaa urakoitsijoita käyttämällä. Myös tilapäisille työntekijöille olisi merkittävä tarve.

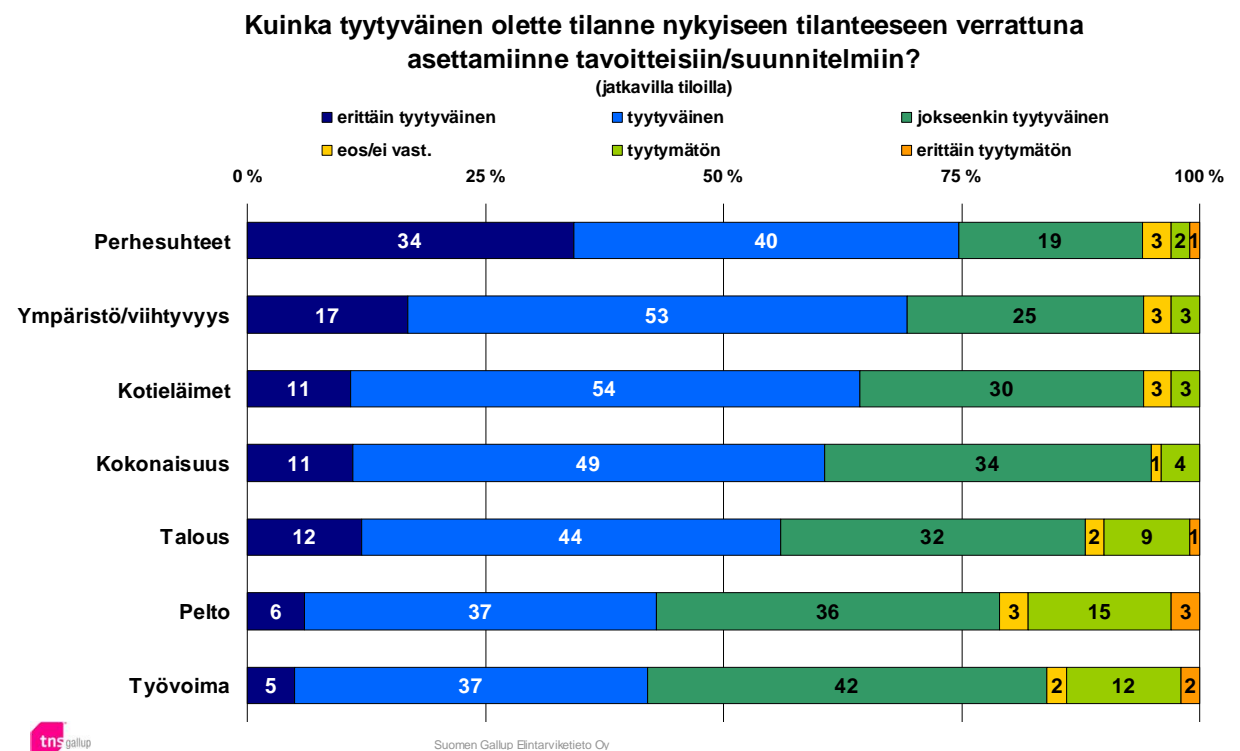

KUVIO 8. Pohjois-Savolaisten maidontuotanto yrittäjien tyytyväisyys oman tilan toimintaan, asetettujen tavoitteiden mukaan.

Tilan toiminnan kannalta tärkeä asia on, että tilan toimintaa pystytään kehittämään jatkuvasti. Etenkin sukupolvenvaihdoksen jälkeen tilaa kehitetään merkittävästi ja tilalle tehdään suuria investointeja. Kun tämä vaihe ohitetaan, alkaa tiloilla usein jäähdyttelyvaihe ja keskitytään pääsääntöisesti tilan velkojen maksamiseen. Haastatelluista yrittäjistä 9 on suunnitellut tilansa toiminnan tämän tyyppisen elinkaaren mukaan. Seuraavat kehittämiskohteet jätetään jo varsin aikaisessa vaiheessa seuraavan yrittäjäsukupolven päätettäviksi. Vaikka seuraavalle sukupolvelle tarjottaisiin vapaita käsiä tilan kehittämiseen, se syö myös seuraavan sukupolven maksuvalmiuskykyä. Heikko maksuvalmiuskyky vaikeuttaa taas sukupolven vaihdoksen jälkeistä kehittämisvaihetta, tämän ongelman mainitsi erityisesti kolme tilaa. Toisaalta taas vanhat tehottomat käytänteet saattavat siirtyvät seuraavalle sukupolvelle ja niistä on vaikea luopua.

Tilalla käytetty teknologia saattaa olla myös tilan toiminnan kehittymisen esteenä. Navetan tekniikka suunnitellaan sen hetken tietämyksen mukaan, tämä saattaa asettaa rajoitteita taloudellisti järkevien tekniikoiden hyödyntämiseen tulevaisuudessa. Osalla haastatelluista tiloista ruokintajärjestelmät ovat toimivia vain täysrehulla ja ohralla. Tämä estää edullisten rehukomponenttien käytön tulevaisuudessa ja asettaa tilan talouden aika ajoin muita tiloja epäedullisempaan asemaan. Yhdellä haastatelluista tiloista esimerkiksi oli uusi ruokintajärjestelmään jouduttu tekemään merkittäviä uudistuksia, jotta uusia rehukomponentteja pystyttiin ottamaan käyttöön. Ruokintajärjestelmät estävät osittain myös peltoviljelyn uusien menetelmien käytön ja vaikeuttavat tilojen riskinhallintaa. Tämä pakottaa tilat epäedullisiin investointeihin tulevaisuudessa. Uusi tuotantorakennus on saatettu rakentaa paikkaan, joka estää toiminnan tulevaisuudessa ja pakottaa yrittäjän taloudellisesti erittäin vaikeaan ratkaisuun.

Tilan taloudenhallinta perustuu usein hetkellisen taloustilanteen arviointiin. Laskelmat tehdään hetkelliseen rahatilanteeseen ja kokemusperäiseen rahavirtojen arvioon perustuen. Taloutta seurataan myös verokirjanpidon avulla, mikä tehdään vuoden päätteeksi. Talouden hetkellisestä tilanteesta ollaan selvillä, mutta talouden pitkäaikaisia vaikutteita ei tunneta. Aktiivista budjetointia tehtiin vain yhdellä kahdestakymmenestä haastatellusta tilasta ja maksuvalmiuslaskelmia harvoin päivitetään investointien jälkeen. Tämä saattaa vaikeuttaa nopeiden investointipäätösten tekoa ja tarjouserien käyttöä. Tietämättömyys lisää myös taloudellista epävarmuutta etenkin muuttuvassa toimintaympäristössä. Talouden suunnittelemattomuus antaa heikot lähtökohdat tilan pitkäjänteiselle kehittämiselle, vaikuttaa kehittämishalukkuuteen ja - mahdollisuuksiin. 
Tilakoon kasvaessa perinteiset roolit isäntänä ja emäntänä menettävät merkitystään päivittäisissä karjanhoitotöiden rutiineissa. Teknologiaratkaisut muuttavat perinteisten töiden tasapainoa ja rikkovat totuttuja rutiininomaisia karjanhoitotöitä. Haastatelluista tiloista neljällä oli tietoisesti siirrytty suunnittelemaan päivittäiset työt aamulla tai toinen yrittäjistä on ottanut vastuun työnjohdosta. Yhdellä tilalla töiden suunnitteluun oli jouduttu kiinnittämään parempaa huomiota sillä tilalle oli palkattu työntekijä johdosta. Töitä täytyy suunnitella eri lähtökohdista ja niihin on löydettävä parempaa johdonmukaisuutta. Suunnittelemattomat työt johtavat usein siihen, että töissä ei kyetä hyödyntämään kaikkea tarjolla olevaa kapasiteettia. Rutiinien avulla maatiloilla töiden suunnittelu helpottuisi. Rutiinien sijoittelun avulla voidaan helposti vaikuttaa jopa oman työpäivän pituuteen ja tehokkuuteen. Suunnitellut ja kirjatut työt helpottaa myös kriittisten pisteiden määrittelyä omassa toiminnassa, joka auttaa töiden priorisoinnissa ja sitä kautta tehostaa työntekoa ja vaikuttaa merkittävästi yrittäjän työaikaan. Tanskassa rutiinien kirjaamisen avulla oli siirrytty enemmän prosessijohtamisen malliin. Rutiinien analysoinnin myötä työn tekemistä oli saatu tehostettua ja niitä oli käytetty apuna myös laajennusten suunnittelussa. Rutiininomaiset työt voidaan suunnitella esimerkiksi viikoittaisiksi tai kahden viikon mittaisiksi kokonaisuuksiksi.

\section{Johtopäätökset}

Yritysmäisempi lähestymistapa ja yrittäjän rooli auttaa löytämään uusia näkökulmia toiminnan tehostamiseksi. Tämä ei välttämättä aina tarkoita tilakoon kasvattamista vaan aiempaa parempaa resurssien hyödyntämistä. Toisaalta resurssien luomat rajoitteet eivät kuitenkaan estä tilan kehittymistä ja laajentamista. Pitkäjänteiset suunnitelmat auttavat tilan kehittämisessä ja auttavat yrittäjää tekemään nopeitakin päätöksiä tilanteen sen salliessa. Tämä edellyttää talouden prosessien yksityiskohtaista tuntemista sekä pitkäntähtäimen vaikutusten ymmärtämistä.

Tärkein resurssi tiloilla on yrittäjien työpanos. Tekniset valmiudet ja niihin liittyvä parantunut toiminnallisuus tiedostetaan, mistä kertoo yrittäjien valmiudet hoitaa yhä suurempia tiloja. Toiminnan kriittisen analysoinnin puuttuminen vaikuttaa kuitenkin tilalla olevien resurssien käyttöön. Toiminnan analysointi helpottaa myös toiminnan uudelleensuunnittelua ja sen yksinkertaistamista. Kriittisten pisteiden määritteleminen suuntaa toiminnan fokusta oleellisiin työvaiheisiin. Talouden pitkän aikavälin vaikutusten heikko tuntemus heikentää myös tilojen mahdollisuuksia vastata muutokseen. Tilojen rakenne ei myöskään salli suuria toimintojen muutoksia. Tilojen teknologiavalinnat tulisi suunnitella siten, että ne mukautuisivat mahdollisimman hyvin tilan tuleviin kehittämistarpeisiin.

Tarkat suunnitelmat ja niiden seuranta sekä analysointi parantavat myös yrittäjän henkistä jaksamista. Mikäli suunnitelmat ennustavat positiivista kehitystä ja suunnitelmissa kyetään pysymään, tuottaa se onnistumisen tunnetta ja varmuutta, että suunnitelmat ovat pitäviä. Yksityiskohtaisiin suunnitelmiin on helppo myös lisätä uhkakuvia ja laskea niiden vaikutusta pitkällä tähtäimellä. Yksityiskohtaiset suunnitelmat, edellyttää pitkää kokemusta niiden tekemisestä, jotta kaikki tekijät osataan ottaa huomioon. Esimerkiksi tarkalla budjetilla ja maksuvalmiuslaskelmilla voidaan ennustaa kiintiöjärjestelmän vaikutuksia tilakohtaisesti jo varsin tarkasti. Hyvin tehtyjä yksinkertaisia laskelmia on helppo päivittää kun saadaan tarkempia tietoja. Ensimmäiset vaikutukset on arvioitu jo Lehtosen 2007 toimittamassa MTT:n selvityksessä 144 ja nämä tulevat vielä päivittymään. Selvityksiä tulee lisää, mutta tiloilla on jo suunnittelun ansiosta mahdollisuus valmistautua tehtävään päätökseen. Yrittäjät ovat myös valmiita vastaamaan tilanteeseen, oli päätöksen vaikutus mikä tahansa. Parhaimmassa tapauksessa kehitys on ollut pitkäjänteistä ja toimintaa on kehitetty ja tilalla maksuvalmius kehittynyt. Tilanteen ollessa selvä yrittäjä kykenee jatkamaan, laajentamaan tai jopa lopettamaan tuotannon kannattavasti.

Maitotilojen kehittyminen ei aina tarvitse investointeja. Se voi tapahtua työn käytön tehostamisen kautta. Työvoiman kannalta tilalla tulisi miettiä töiden suunnittelemista eri näkökulmasta. Viikoittaiset ja kuukausittaiset työrutiinit tuovat selkeyttä töiden organisointiin sekä rajaavat yrittäjien työpäivien pituutta. Se helpottaa myös ulkopuolisen työntekijän sopeutumista uuteen ympäristöön. Kirjatut rutiinit helpottavat kriittisten pisteiden määrittämisessä ja toiminnan priorisointia. Huolellinen töiden suunnittelu parantaa työn tekemisen laatua ja helpottaa niiden siirtämistä ulkopuolisen hoidettavaksi töiden laadun vaarantumatta. Huolellinen suunnittelu auttaa myös määrittelemään työkokonaisuuksia, jotka voidaan antaa ulkopuolisten hoidettavaksi. 


\section{Kirjallisuus}

Lehtonen (toim.) 2007. EU:n maitokiintiöjärjestelmän poistumisen vaikutukset Suoman maitosektorille. MTT:n selvityksiä 144. [Viitattu: 30.11.2007] Saatavissa internetistä: http://www.mtt.fi/mtts/pdf/mtts144.pdf

Suomen Gallup Elintarviketieto Oy. 2006. AgriInfo, Maatilojen tulot ja pääostopanosten menot 2005. TNS Gallup Oy.

Suomen Gallup Elintarviketieto Oy. 2006. Maidontuotantoennusteet 2012 Suomessa. TNS Gallup Oy. 